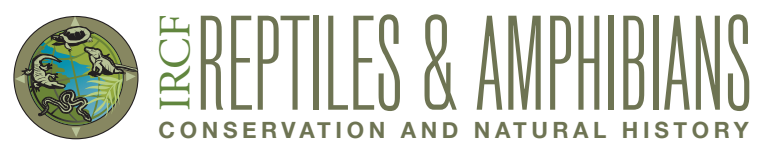

\title{
Differential Habitat Use by Common Watersnakes (Nerodia sipedon)
}

Lorin A. Neuman-Lee ${ }^{1,2}$, Andrew M. Durso ${ }^{1,2}$, Nicholas M. Kiriazis ${ }^{1,3}$, Melanie J. Olds ${ }^{1,4}$, and Stephen J. Mullin ${ }^{1}$

${ }^{1}$ Department of Biological Sciences, Eastern Illinois University, Charleston, Illinois 61920, USA

${ }^{2}$ Present address: Department of Biology, Utah State University, Logan, Utah 84321, USA (lorin215@gmail.com)

${ }^{3}$ Present address: School of Teacher Education and Leadership, Utah State University, Logan, Utah 84321, USA

${ }^{4}$ Present address: Delaware Water Gap National Recreation Area, Bushkill, Pennsylvania 18324, USA

Abstract.-Understanding intraspecific variation in habitat use is important for the management of any species. In many studies of reptiles, habitat use by juveniles is poorly understood when compared to their adult conspecifics because of capture biases and logistical constraints. We compared habitat use between sexes and age classes of Common Watersnakes (Nerodia sipedon) at a reservoir in central Illinois. Juvenile $N$. sipedon occurred more frequently in habitat with high canopy cover, whereas adult $N$. sipedon, especially reproductive females, were found exclusively in habitat with no canopy cover. Adult males used both locations equally. We emphasize the need to investigate ontogenetic variation in habitat use to better understand how reptiles utilize diverse anthropogenically altered landscapes.

Tn order to effectively comprehend the biology of a species, an understanding of habitat use by all life-history stages is necessary. Studies that investigate a single species usually rely on radio telemetry (Carfagno and Weatherhead 2006,
Madsen 1984, Reinert 1984, Shine 1987), a technique that is often limited to focal individuals (usually having larger body sizes) over a relatively short time period. Studies of aquatic snakes have emphasized the importance of investigating onto-

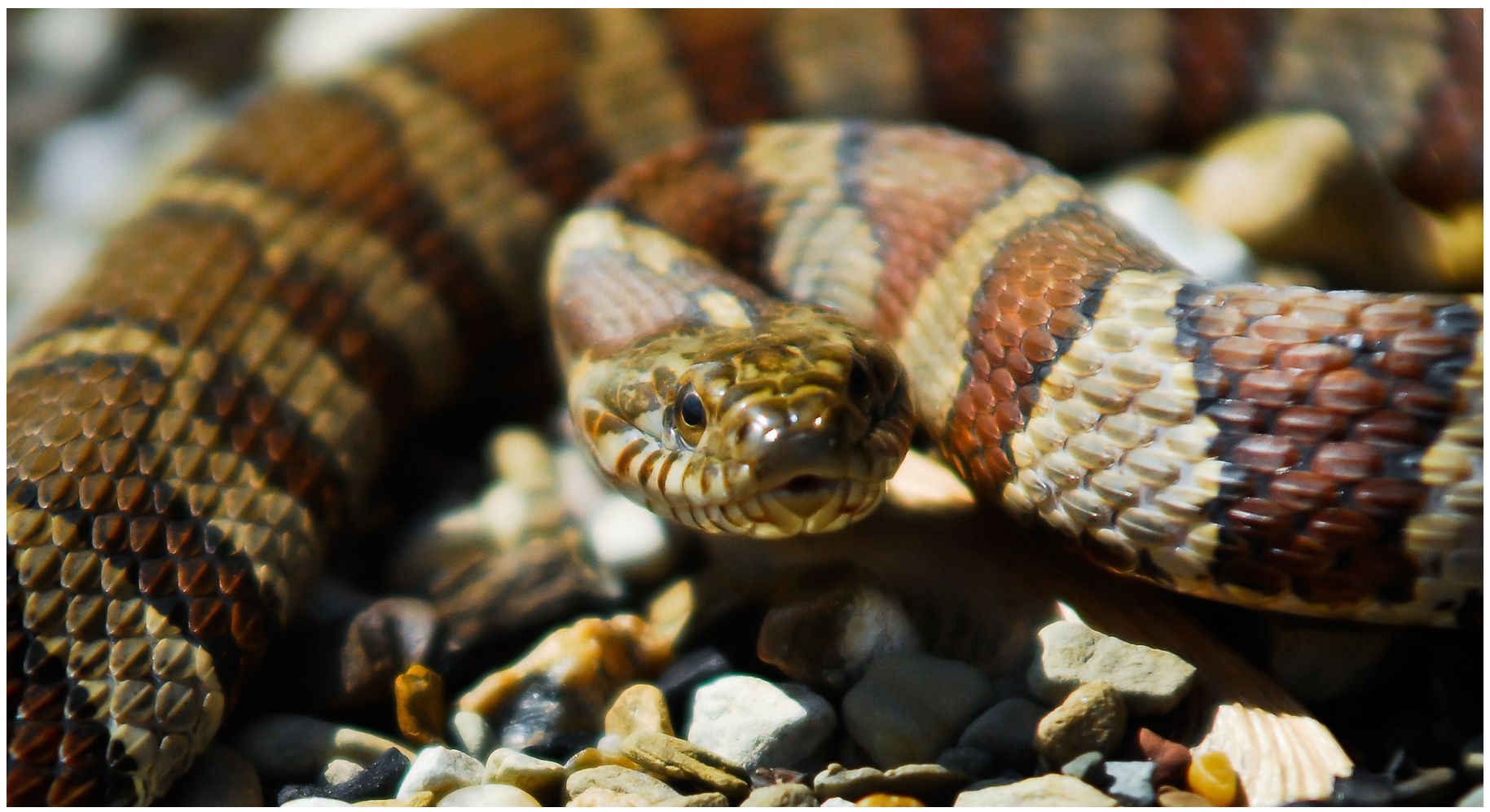

Fig. 1. Adult female Common Watersnake (Nerodia sipedon). Photograph by N.M. Kiriazis. 


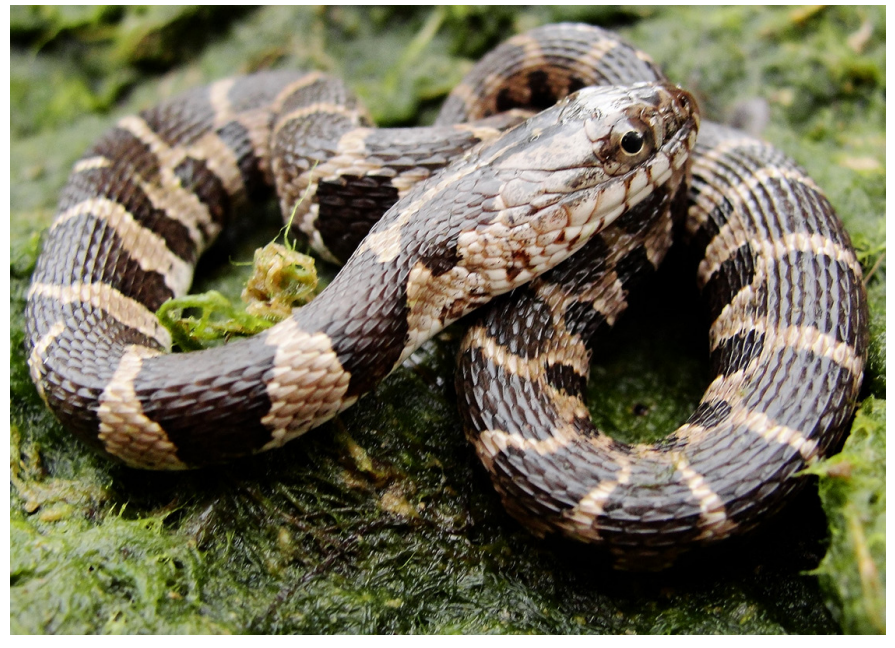

Fig. 2. Juvenile Common Watersnake (Nerodia sipedon). Photograph by L.A. Neuman-Lee.

genetic variation in habitat use before making generalizations (Lacy 1995, Savitzky and Burghardt 2000). Habitat use of aquatic juvenile snakes often is difficult to observe, however, because of capture biases (Rodda et al. 2007, Semlitsch and Moran 1984, Todd et al. 2007, Willson et al. 2008) and the size constraints of radio transmitters (Pattishall and Cundall 2008, Roth and Greene 2006, Tiebout and Cary 1987). Recently, researchers have examined juvenile pitviper ecology using advancements in transmitter technology (Cobb et al. 2005, Jellen and Kowalski 2007), yet this type of work still is constrained by basic logistics of snake and transmitter size. Long-term data on juvenile habitat use should inform population management efforts, especially in cases where juveniles differ from adults in their patterns of habitat use.

We monitored a population of Common Watersnakes (Nerodia sipedon; Figs. $1 \& 2$ ) over a period of five years at two adjacent sites. We examined the effect that differences in habitat have on variation in use by different life-history stages of $N$. sipedon. We predicted that juvenile $N$. sipedon would use different habitats from adult snakes due to their smaller size and different prey requirements. Further, due to sexual dimorphism and different thermoregulatory requirements, we predicted that adult male and female $N$. sipedon would occur with differing frequencies in the two habitats.

\section{Materials and Methods}

Study Site.-The study site is located at the Charleston Side-Channel Reservoir in Coles County, Illinois, USA $\left(39.464875^{\circ} \mathrm{N},-88.143871^{\circ} \mathrm{W}\right.$; WGS 84), a 142 -ha impoundment of the Embarras River. The river flows along a channel and over a low-head dam to the southeast of a levee. Upstream from the dam, water is pumped from the river into the reservoir, which is west of the levee and has negligible flow (Austen et al. 1993). Within this site, we sampled two distinct riparian habitats, the levee (Fig. 3) and the spillway/dam (Fig. 4 ), that are separated by $180 \mathrm{~m}$ of straight-line distance and $260 \mathrm{~m}$ of river length. We measured canopy cover at five locations within each habitat using a spherical densiometer.

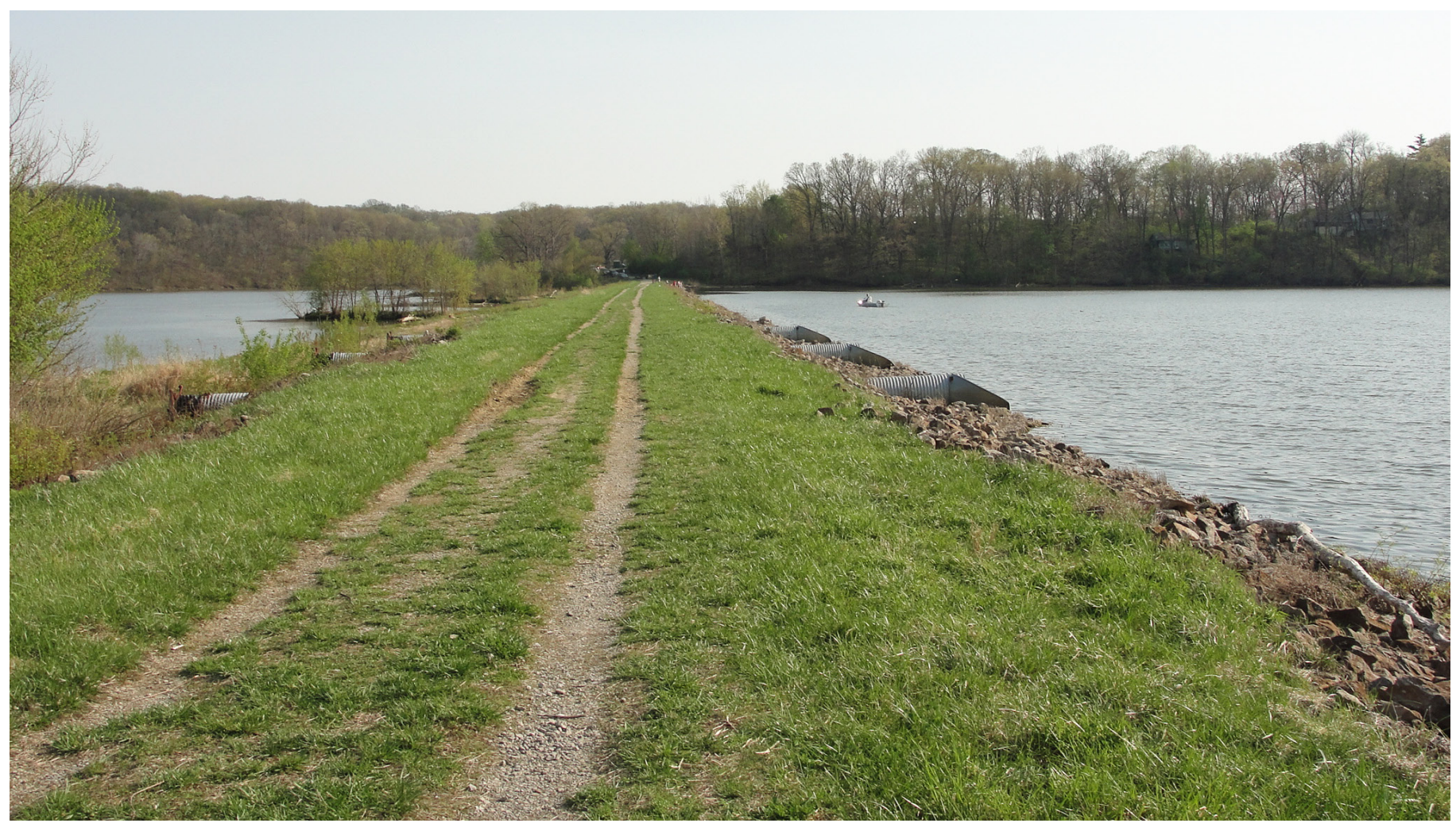

Fig. 3. View of the levee separating the Embarras River and Charleston Side-Channel Reservoir in Coles County, Illinois. Photograph by L.A. Neuman-Lee. 


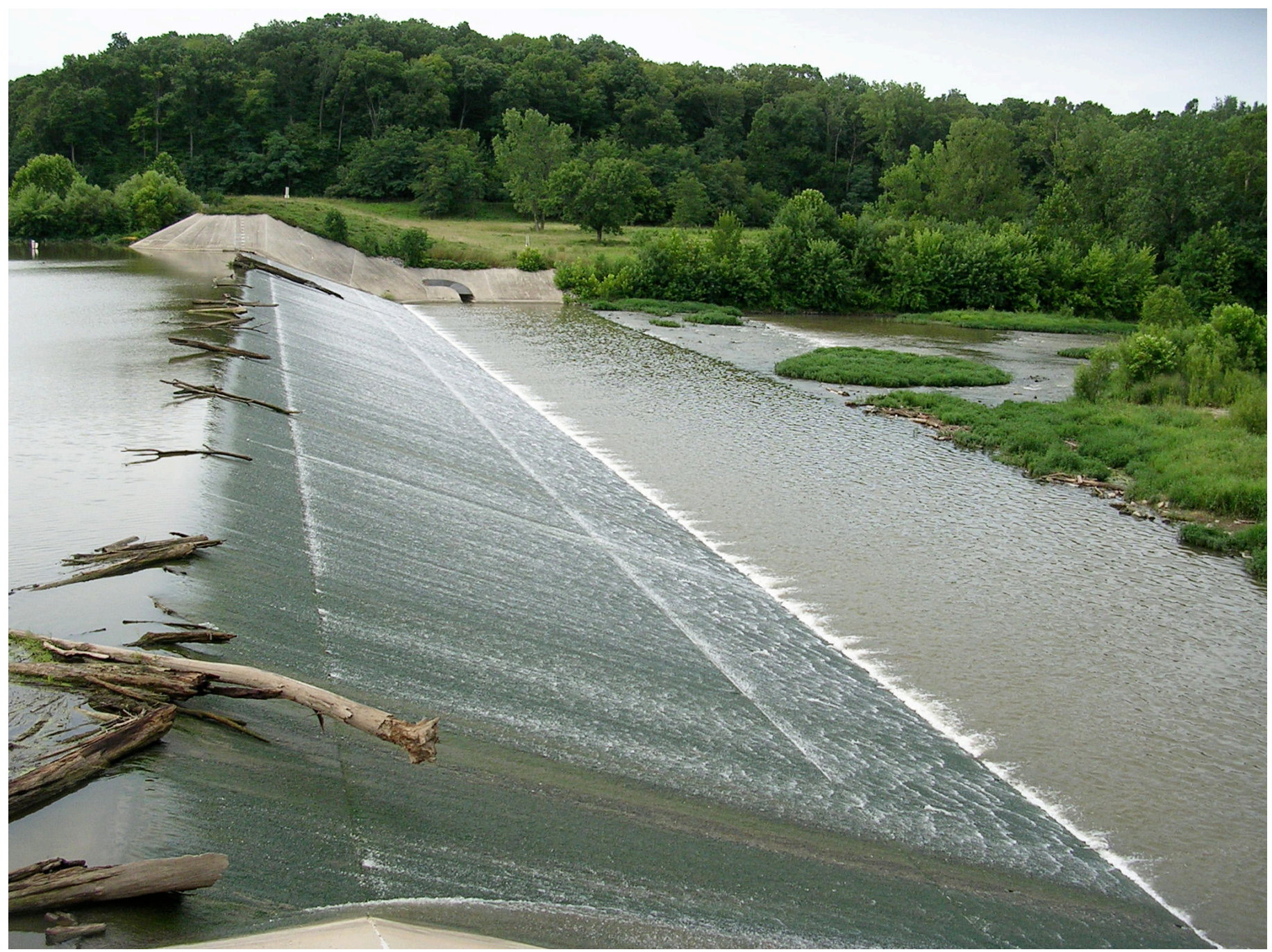

Fig. 4. View of the dam/spillway on the Embarras River in Coles County, Il linois. Photograph by S.J. Mullin.

Animal Collection.-We collected snakes during 5-16 days between 27 March and 18 September in each of five years (2006-2010). Between one and five experienced observers participated in each day of snake collection. Effort was variable, but was approximately equal between the levee and the dam. We did not correct for capture effort because it could not be precisely quantified across years.

All snakes were collected by hand or noose. We determined the sex and mass $( \pm 0.1 \mathrm{~g})$ of each snake, and measured its snout-vent length (SVL) and tail length $( \pm 1 \mathrm{~mm})$. A female snake was considered adult when her SVL was at least $600 \mathrm{~mm}$ (Weatherhead et al. 1995), whereas a male was considered adult at $430 \mathrm{~mm}$ (King 1986). We palpated adult female snakes for the presence of developing embryos. Snakes were marked with a medical cauterizer directly anterior to the cloaca on the ventral and lateral scales so that recaptures could be identified (Winne et al. 2006). All snakes were released at sites of capture.

Statistical Analyses. - Because SVL and body mass were correlated $\left(\mathrm{r}^{2}=0.89 ; \mathrm{P}<0.0001\right)$, we used only mass in our analyses. We did not include recaptures in any analysis. We compared the number of animals of each sex and age class found in each habitat using chi-squared tests. Additionally, we compared the size of adult and juvenile snakes of both sexes among habitats using Mann-Whitney Rank Sum tests, with mass as the response variable and location, sex, age, and their interactions as explanatory variables. We also compared the size of adult and juvenile snakes of each sex independently between sites. All statistics were performed using SAS 9.3 (SAS Institute Inc. 2011), with alpha set at 0.05.

\section{Results}

Canopy cover was higher in the habitat surrounding the dam $(43.5 \pm 18.6 \%$; Table 1$)$ than at the levee $(0 \pm 0 \%)$, although a variance of 0 at the levee precluded meaningful statistical analysis. Other measures of differences between the two habitats, obtained from the literature, include differences in habitat structure and syntopic prey and predator species, especially fishes (Table 1). 
Table 1. Quantitative and qualitative site characteristics of two habitats at Charleston Side-Channel Reservoir, Coles County, Illinois, USA.

\begin{tabular}{lccl} 
& Levee & Dam & Source \\
\hline Canopy cover & $0 \pm 0 \%$ & $43.5 \pm 18.6 \%$ & This study \\
\hline Rubble & High & Low & Austen et al. 1993 \\
\hline Flow rate & Low & High & Demissie et al. 1986 \\
\hline Water depth & $>\mathrm{m}$ & $<1 \mathrm{~m}$ & Austen et al. 1993, Demissie et al. 1986 \\
\hline Neonate predators* & High & Moderate & Austen et al. 1993, Fornell 2008, Frothingham et al. 2001 \\
\hline Small prey fishes & Low & High & Austen et al. 1993, Frothingham et al. 2001
\end{tabular}

* ophiophagus snakes and large fishes

In 50 days of surveying, we captured 197 individual snakes. An average of $4 \pm 0.6$ snakes were caught per day, with at least one and as many as 21 snakes caught on a single day. Of these, 104 were male and 93 were female; 51 were juveniles and 146 were adults. A similar number of juvenile and adult snakes of each sex was captured $\left(\chi^{2}{ }_{196,1} \leq 0.61\right.$; $\mathrm{P}$ $\geq 0.42$ ). The overall sex ratio was 0.88 females to 1 male. A similar total number of snakes was captured in each habitat $\left(\chi_{196,1}^{2}=0.86 ; \mathrm{P}=0.35\right)$.

Habitat use differed between sexes and age classes. Regardless of size, the sex ratio at the dam $(0.66: 1)$ was male-biased $\left(\chi_{104,1}^{2}=4.2 ; \mathrm{P}=0.04\right)$, whereas the sex ratio at the levee was more balanced $\left(1.2: 1 ; \chi_{91,1}^{2}=1.1 ; \mathrm{P}=0.29\right)$. The habitat adjacent to the dam also contained more juvenile snakes than that at the levee $\left(\chi_{50,1}^{2}=32.9 ; \mathrm{P}<0.0001\right)$. The sex ratio of juveniles did not differ from 1:1 at either

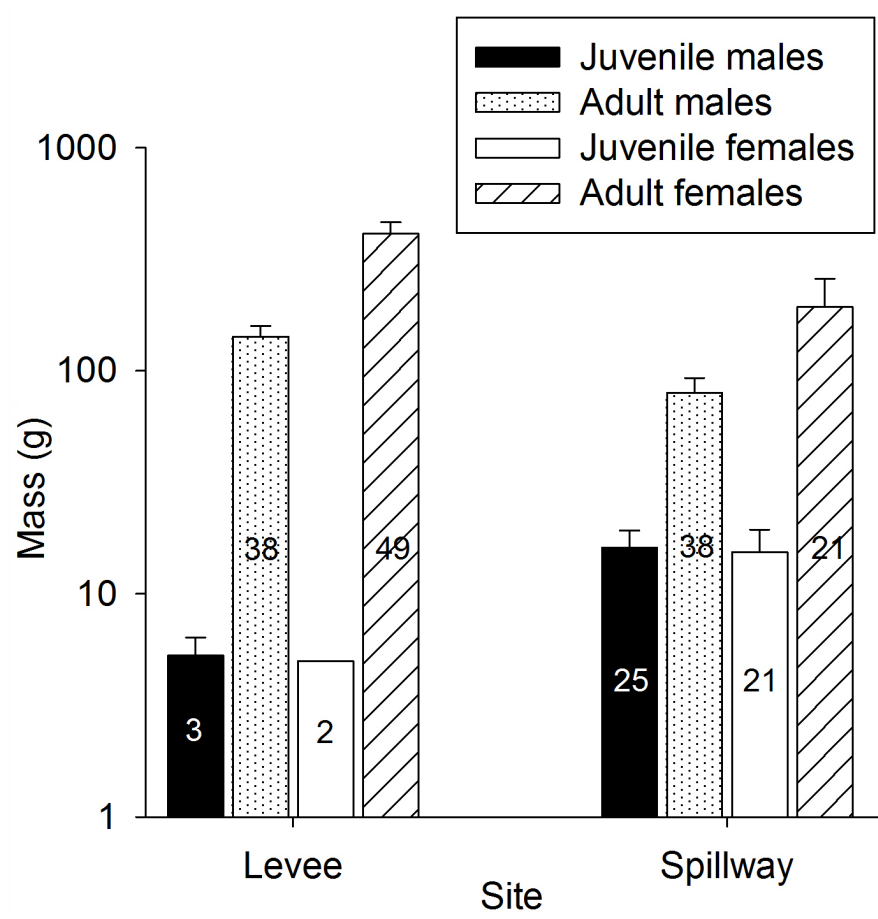

Fig. 5. Differences in mass of Common Watersnakes (Nerodia sipedon) between two habitats in Coles County, Illinois. Bars represent $\pm 95 \%$ CI. Sample sizes are displayed within each bar. site $\left(\chi^{2} \leq 0.2 ; \mathrm{P} \geq 0.55\right)$, whereas the sex ratio of adults was skewed toward males at the dam $\left(\chi_{58,1}^{2}=4.9 ; \mathrm{P}=0.027\right)$, but not at the levee $\left(\chi_{86,1}^{2}=1.4 ; \mathrm{P}=0.24\right)$. Adult female snakes were captured more frequently at the levee $\left(\chi_{69,1}^{2}=11.2\right.$; $\mathrm{P}<$ $0.001)$, whereas adult male snakes were found with equal frequency between the two habitats $\left(\chi_{75,1}^{2}=0 ; \mathrm{P}=1.0\right)$. During months when determining whether adult female snakes were gravid was possible, $100 \%$ of gravid females were captured at the levee.

At both sites, juveniles did not differ in size between sexes $(\mathrm{P}=0.9$; Fig. 5$)$, whereas adult females were larger than adult males. This difference was more pronounced at the levee $(\mathrm{P}$ $<0.001)$ than at the dam $(\mathrm{P}=0.006)$. Independent of sex, smaller adult snakes $(\mathrm{P}<0.001)$ and larger juvenile snakes $(\mathrm{P}$ $=0.008)$ were found in habitat adjacent to the dam. Adult males $(\mathrm{P}<0.001)$ and adult females $(\mathrm{P}<0.001)$ were larger at the levee than at the dam.

\section{Discussion}

Nerodia sipedon is a habitat generalist that uses a diverse and complex environment (Gibbons and Dorcas 2004, Tiebout and Cary 1987). Our results reinforce this conclusion and demonstrate the importance of sampling multiple microhabitats when assessing populations of a generalist species. At our site, sampling only one habitat would have provided a misleading impression of population sex ratio, size, and age structure. Although adult males used the two habitats equally, adult females were found disproportionately on the levee and juveniles were found predominantly at the dam.

In the midwestern United States, female $N$. sipedon become reproductively mature when they are between 475 and $680 \mathrm{~mm}$ (Bauman and Metter 1977, Feaver 1977, King 1986, Weatherhead et al. 1995). We suggest that the observed difference in adult female size between the two habitats is due to females migrating to, and preferentially occupying, the levee habitat upon reaching sexual maturity. The riparian habitat at the levee is composed of large, haphazardly stacked rocks, which would allow snakes to thermoregulate precisely by selecting different distances from the surface. In this way, the high, stable temperatures preferred by gravid female viviparous snakes (Charland 1995, Charland and Gregory 1990, 
Huey et al. 1989, Tu and Hutchison 1994) can be reached with minimal exposure to predation. The dam habitat has less complex structure and also is more shaded and therefore presumably cooler (Table 1 ). Adult female $N$. sipedon at our site overwinter near or within the levee (Olds 2007) and were not found at the dam during any time period, suggesting that they also give birth at the levee. Therefore, juveniles must disperse from the levee relatively quickly, because many were found in habitat downstream from the dam.

A variety of advantages to dispersal from the levee to the dam are possible. Most of the open-water habitat along the levee is $>2 \mathrm{~m}$ deep whereas the open-water habitat immediately downstream from the dam is shallower $(<1 \mathrm{~m}$ deep; Austen et al. 1993). Evidence for ontogenetic shifts from shallow to deep-water habitats has been found for both freshwater and marine aquatic snakes (Savitzky and Burghardt 2000, Shine et al. 2003). In this system, a primary cause of this microhabitat shift could be to avoid predation or competition from centrarchid fishes present at the levee but absent from the dam area (Austen et al. 1993, Frothingham et al. 2001). Additionally, neonate $N$. sipedon in our system might emigrate to avoid a terrestrial predator, Prairie Kingsnakes (Lampropeltis calligaster, Fornell 2008), found predominantly along the levee. Finally, smaller prey fishes ideal for juvenile $N$. sipedon, such as percids and cyprinids, are more abundant at the dam than at the levee (Bowen 2004, Frothingham et al. 2001). This dispersal pathway might be facilitated by the river's direction of flow, which could sweep neonate $N$. sipedon downstream to the more favorable dam habitat at minimal energetic cost to the snakes.

Adult male $N$. sipedon were equally abundant in both habitats, although they were larger on the levee than at the dam. Male Nerodia are more aquatic and spend less time and energy thermoregulating than either reproductive or nonreproductive females (Brown and Weatherhead 2000, Camper and Chick 2010), suggesting that their habitat requirements are less specific than female conspecifics. Although one pair of snakes was observed mating at the dam, all other mating was observed at the levee. Therefore, we suggest that most reproductive males migrate upstream from the dam to the levee in search of reproductive females.

Differences in habitat quality partially explain the differential use of habitats by life-history stages of $N$. sipedon. The rocky, open levee habitat probably allows gravid females to select a warmer optimal thermal microenvironment for gestation, but is probably not conducive to survival of neonates because of exposure to predation and lower prey availability. In contrast, the dam has more canopy cover to obscure small snakes from avian predators and contains a higher prey density for juvenile snakes, but it offers an inadequate thermal microhabitat for reproductively-active females. Comprehensive studies can aid in a greater understanding of the ecology of watersnakes in complex anthropogenically altered environments.

\section{Acknowledgments}

We are grateful to the following individuals, who aided in data collection: Kyle Baumgartner, Todd Bollinger, Keith Butler, Angela Fornell, Iwo Gross, Lee Gross-Diana, Kate Hale, Jenni Hedin, Mary Jo Kocher, Jeff Neuman-Lee, Judi Neuman-Lee, and the Eastern Illinois University (EIU) Herpetology classes of 2007 and 2009. Comments from the herpetology groups at EIU and Utah State University greatly improved the manuscript. This work was conducted in accordance with EIU IACUC permit \#08-010.

\section{Literature Cited}

Austen, D.J., J.T. Peterson, B. Newman, S.T. Sobaski, and P.B. Bayley. 1993. Compendium of 143 Illinois lakes: Bathymetry, physico-chemical features, and habitats. Volume 1 - Lakes in Regions 1, 2, and 3. Center for Aquatic Ecology, Champaign, Illinois.

Bauman, M.A. and E. Metter. 1977. Reproductive cycle of the Northern Watersnake, Natrix s. sipedon (Reptilia, Serpentes, Colubridae). Journal of Herpetology 11:51-59.

Bowen, K.D. 2004. Geographic and size-related variation in the diet of insular populations of the Northern Watersnake. American Midland Naturalist 152:418-424.

Brown, G.P. and P.J. Weatherhead. 2000. Thermal ecology and sexual size dimorphism in Northern Water Snakes, Nerodia sipedon. Ecological Monographs 70:311-330.

Camper, J.D. and L.D. Chick. 2010. Seasonal variation in the spatial ecology of the Banded Watersnake (Nerodia fasciata fasciata). Herpetologica 66:464-475.

Carfagno, G.L.F. and P.J. Weatherhead. 2006. Intraspecific and interspecific variation in use of forest-edge habitat by snakes. Canadian Journal of Zoology 84:1440-1452.

Charland, M.B. 1995. Thermal consequences of reptilian viviparity: Thermoregulation in gravid and nongravid garter snakes (Thamnophis). Journal of Herpetology 29:383-390.

Charland, M.B. and P.T. Gregory. 1990. The influence of female reproductive status on thermoregulation in a viviparous snake, Crotalus viridis. Copeia 1990:1089-1098.

Cobb, V.A., J.J. Green, T. Worrall, J. Pruett, and B. Glorioso. 2005. Initial den location behavior in a litter of neonate Crotalus horridus (Timber Rattlesnakes). Southeastern Naturalist 4:723-730.

Demissie, M., W.C. Bogner, V. Tsihrintzis, and N.G. Bhowmik. 1986. Channel scour induced by spillway failure at Lake Charleston, Illinois. Illinois State Water Survey Division, Illinois Department of Energy and Natural Resources, Champaign, Illinois.

Feaver, P.E. 1977. The demography of a Michigan population of Natrix sipedon with discussions of ophidian growth and reproduction. Ph.D. dissertation, University of Michigan, Ann Arbor.

Fornell, A.M. 2008. Foraging Site Selection in Prairie Kingsnakes (Lampropeltis c. calligaster): An Experimental Approach. M.S. Thesis, Eastern Illinois University, Charleston.

Frothingham, K.M., B.L. Rhoads, and E.E. Herricks. 2001. Stream geomorphology and fish community structure in channelized and meandering reaches of an agricultural stream, pp. 105-118. In: J. Dorava, D. Montgomery, B. Palcsak, and F. Fitzpatrick (eds.), Geomorphic Processes and Riverine Habitat. American Geophysical Union, Washington, D.C.

Gibbons, J.W. and M.E. Dorcas 2004. North American Watersnakes: A Natural History. University of Oklahoma Press, Norman.

Huey, R.B., C.R. Peterson, S.J. Arnold, and W.P. Porter. 1989. Hot rocks and not-so-hot rocks: Retreat-site selection by garter snakes and its thermal consequences. Ecology 70:931-944.

Jellen, B.C. and M.J. Kowalski. 2007. Movement and growth of neonate Eastern Massasaugas (Sistrurus catenatus). Copeia 2007:994-1000.

King, R.B. 1986. Population ecology of the Lake Erie Water Snake, Nerodia sipedon insularum. Copeia 1986:757-772.

Lacy, G.B. 1995. Food habits of the Midland Watersnake, Nerodia sipedon pleuralis, in a Piedmont creek, with comments on its population structure. M.S. Thesis, Georgia College and State University, Milledgeville. 
Madsen, T. 1984. Movements, home range size and habitat use of radio-tracked Grass Snakes (Natrix natrix) in southern Sweden. Copeia 1984:707-713.

Olds, M. 2007. Habitat use and overwintering ecology of the Northern Watersnake (Nerodia sipedon) on an artificial levee in Central Illinois. M.S. Thesis, Eastern Illinois University, Charleston.

Pattishall, A. and D. Cundall. 2008. Spatial biology of Northern Watersnakes (Nerodia sipedon) living along an urban stream. Copeia 2008:752-762.

Reinert, H.K. 1984. Habitat varition within sympatric snake populations. Ecology 65:1673-1682.

Rodda, G.H., J.A. Savidge, C.L. Tyrrell, M.T. Christy, and A.R. Ellingson. 2007. Size bias in visual searches and trapping of Brown Treesnakes on Guam. Journal of Wildlife Management 71:656-661.

Roth, T.C. and B.D. Greene. 2006. Movement patterns and home range use of the Northern Watersnake (Nerodia sipedon). Copeia 2006:544-551.

Savitzky, B.A., and G.M. Burghardt. 2000. Ontogeny of predatory behavior in the aquatic specialist snake, Nerodia rhombifer, during the first year of life. Herpetological Monographs 14:401-419.

Semlitsch, R.D. and G.B. Moran. 1984. Ecology of the Redbelly Snake (Storeria occipitomaculata) using mesic habitats in South Carolina. American Midland Naturalist 111:33-40.

Shine, R. 1987. Intraspecific variation in thermoregulation, movements and habitat use by Australian Blacksnakes, Pseudechis porphyriacus (Elapidae). Journal of Herpetology 21:165-177.

Shine, R., T. Shine, and B. Shine. 2003. Intraspecific habitat partitioning by the sea snake Emydocephalus annulatus (Serpentes, Hydrophiidae): The effects of sex, body size, and colour pattern. Biological Journal of the Linnean Society 80:1-10.

Tiebout, H., III and J. Cary. 1987. Dynamic spatial ecology of the water snake, Nerodia sipedon. Copeia 1987:1-18.

Todd, B.D., C.T. Winne, J.D. Willson, and J.W. Gibbons. 2007. Getting the drift: Examining the effects of timing, trap type and taxon on herpetofaunal drift fence surveys. American Midland Naturalist 158:292-305.

Tu, M.C. and V.H. Hutchison. 1994. Influence of pregnancy on thermoregulation of water snakes (Nerodia rhombifera). Journal of Thermal Biology 19:255-260.

Weatherhead, P.J., F.E. Barry, G.P. Brown, and M.R.L. Forbes. 1995. Sex ratios, mating behavior and sexual size dimorphism of the Northern Watersnake, Nerodia sipedon. Behavioral Ecology and Sociobiology 36:301-311.

Willson, J.D., C.T. Winne, and M.B. Keck. 2008. Empirical tests of biased body size distributions in aquatic snake captures. Copeia 2008:401-408.

Winne, C.T., J.D. Willson, K.M. Andrews, and R.N. Reed. 2006. Efficacy of marking snakes with disposable medical cautery units. Herpetological Review $37: 52-54$. 